\title{
MET Tyrosine Kinase Inhibitor SAR125844
}

National Cancer Institute

\section{Source}

National Cancer Institute. MET Tyrosine Kinase Inhibitor SAR125844. NCI Thesaurus.

Code C97511.

An inhibitor of the proto-oncogene c-Met (also known as hepatocyte growth factor receptor (HGFR)) with potential antineoplastic activity. Upon intravenous administration, c-Met inhibitor SAR125844 binds to c-Met, thereby disrupting c-Met-mediated signal transduction pathways. This may result in cell growth inhibition in tumors that overexpress c-Met. c-Met, a receptor tyrosine kinase overexpressed or mutated in a variety of cancers, plays an important role in tumor cell proliferation, survival, invasion, metastasis and tumor angiogenesis. 